\title{
LAS FIGURAS REFLEXIVAS DE LA INTERMEDIALIDAD EN LA PELÍCULA. EL CINE EN EL ESPEJO DE LAS ARTES / LAS ARTES EN EL ESPEJO DEL CINE
}

\author{
Ágnes Pethö \\ Universidad Babeș-Bolyai (Cluj)
}

La intermedialidad es un aspecto importante de la reflexividad en diferentes ámbitos del arte. La autorepresentación medial del texto tanto en literatura como en cine, por ejemplo, se realiza muchas más veces a través de otros sistemas de comunicación. En literatura, el estilo reflexivo presenta el texto como un tejido de los sistemas semióticos en una continua oposición (Naugh, 1984: 19). «La pantalla desnuda y muda se extiende ante nosotros como una página en blanco», dice Thomas Pynchon (1973: 760) en su novela Gravity's Rainbow. A su vez, la novela posmoderna se puede describir igualmente a través de la metáfora de la pantalla cinematográfica, afirma Brian McHale (1987: 116). Hay que mencionar, sin embargo, que aunque la heteroglosia o la intertextualidad multimedial es una forma importante de la automatización de la literatura como medio de expresión, este fenómeno no puede ser considerado como una verdadera multimedialidad, 
porque a parte de las ilustraciones o de las posibilidades visuales de la tipografía, la literatura puede integrar otros medios de comunicación sólo por trascripción linguística. La película, por otro lado, es un texto multimedial par excellence, que puede incluir cualquier otra forma de comunicación, por consiguiente sus posibilidades de reflexividad intermedial son múltiples.

Cuando una película trata de su propia medialidad, o mejor dicho, multimedialidad, es decir, su propia red de relaciones con los otros medios de comunicación, la función más importante de esta autopresentación es que, de alguna manera, un ámbito se vuelve el espejo del otro, entonces podemos hablar de una especie de «mise en abyme ${ }^{1}$ intermedial». Claro está que esta afirmación es demasiado general, ya que la reflexividad se puede manifestar a través de diversas estrategias poéticas o figuras retóricas que orientan la recepción de estos textos y pueden constituir puntos de referencia para la interpretación ${ }^{2}$.

En primer lugar podemos distinguir una realización intramedial y una intermedial de esta reflexividad. En el caso de la intramedialidad se trata de una reflexión en el marco del texto entre las diferentes capas de la codificación heterogénea de la película. A diferencia de ésta, a través de la auténtica mise en abyme intermedial se realiza una referencia metalingüística a los distintos sistemas de codificación generadores de textos, a parte del cinematográfico, una referencia al ámbito de las demás artes, una verdadera intertextualidad multimedial.

En cuanto a la intramedialidad en la película, la delimitación de los aspectos de la reflexividad es bastante problemática, dado que los distintos niveles de codificación se sobreponen y pueden producir relaciones semánticas complejas: el lenguaje hablado o escrito puede no sólo completar, sino también comentar la imagen, y las imágenes, la música pueden constituir un comentario audiovisual que se refiere al diálogo o a la narración. Miramos la imagen a través de lo que dicen los

${ }^{1}$ De las definiciones del término, citemos las siguientes: «est mise en abyme toute enclave entretenant une relation de similitude avec l'œuvre qui la contient» (Dällenbach, 1977: 18); «mise en abyme refers to the infinite regress of mirror reflections to denote the literary, painterly, or filmic processes by which a passage, a section, or sequence plays out in miniature the processes of the text as a whole» (StamBurgoyne-Flitterman-Lewis, 1992: xiv).

2 Reconocemos aquí, por supuesto, que se trata de una interpretación reflexiva, en el sentido atribuido a esta modalidad de «formación de sentido» por David Bordwell, en su libro sobre las tendencias existentes en la historia de la crítica de cine en cuanto a las estrategias y a las metáforas predominantes en la interpretación de las creaciones cinematográficas (véase especialmente Bordwell, 1989: 111-115). 
personajes: de hecho, todo el mundo visual y acústico de la película se filtra a través de las informaciones verbales (diálogo, narración, diversas inscripciones, etc.) y por otra parte, los mensajes lingüísticos son contextualizados por las imágenes en cuyo marco aparecen. Esta reflexividad interna de los medios de comunicación en la película es una característica general de la constitución del significado en el cine y, por consiguiente, pertenece al ámbito de los estudios semánticos de la película (de hecho, es uno de los problemas más interesantes de la semántica cognitiva de la película). A continuación, sin embargo, quisiera concentrarme más en el fenómeno que tiene muchos puntos comunes con la noción de mise en abyme. Entre las características definitorias de ésta, hay que mencionar, en primer lugar, las siguientes: la noción se refiere a un fragmento textual, este fragmento es una unidad separada del texto, o en todo caso, que se puede aislar fácilmente del resto del texto ${ }^{3}$. En segundo lugar, en el presente estudio, me refiero a los casos en los que la relación de reflexividad que se da entre las codificaciones de la película implica no sólo aspectos de semántica general, sino también una reflexividad textual medial: entonces, los distintos medios de expresión se reflejan recíprocamente en un plano metalingüístico, sus aspectos mediales, sus distintas posibilidades de comunicación son acentuados a través de una tematización explícita o alegórica en el texto. Esta intramedialidad implica sin embargo, al mismo tiempo, una intermedialidad, o una intertextualidad multimedial. Por consiguiente, las dos categorías se sobreponen muchas veces y la distinción entre ellas es más bien teórica, formal.

Dado que voy a hablar de la retórica de los textos cinematográficos y no de la semántica general multimedial de la película, dejaré de operar sistemáticamente con su dualidad y me voy a centrar en el término de reflexividad (textual) intermedial, que se basa en relaciones intratextuales/intramediales (apuntando, cuando sea relevante desde el punto de vista de la reflexividad, los puntos comunes a las dos categorías). Al considerar los distintos aspectos de la intermedialidad cinematográfica, propiamente dicha, voy a referirme, en primer lugar, a ésta última cualidad mencionada: la de intertextualidad multimedial, empleando pues el término en un sentido restrictivo para hablar de los aspectos «interlingüísticos» generales, en la medida en que la naturaleza de esta intertextualidad pone de manifiesto los aspectos mediales.

3 En este sentido habla Dällenbach de la mise en abyme como un «enclave» (1977: 18), y en el estudio de Mieke Bal aparece: «la relative indépendance de la mise en abyme», «une interruption» (1987: 122). 
Trataré de esbozar las principales tendencias en las que se apoyan las estrategias poéticas intermediales de la reflexividad cinematográfica.

El sistema está lejos de ser perfecto, y en la mayoría de los casos, estas tendencias se combinan, las funciones se sobreponen; sin embargo, se pueden distinguir y aparecen con diferentes acentos en autores y períodos distintos. La base teórica de este intento de tipificación la constituyen, por una parte, las teorías referentes a la autorreferencia textual (teorías de inspiración estructuralista con prolongaciones postestructuralistas y presentes tanto en las discusiones sobre el modernismo, como en las sobre el postmodernismo), y por otra parte, las investigaciones sobre la intermedialidad en la película y algunas orientaciones cognitivas ${ }^{4}$.

\section{REFLEXIVIDAD AUTOTEXTUAL TEMÁTICO/DIEGÉTICA}

Una de las formas de autorrepresentación textual de la película es lo que Lucien Dällenbach (1977: 76) ha llamado una «mise en abyme de l'énoncé, ou fictionnelle». Ésta se realiza en realidad como - un espejo autotextual retrospectivo o prospectivo- un fragmento que tiene funciones anafóricas o catafóricas en el texto, o se puede manifestar como un resumen temático/diegético que concentra estas dos funciones.

Un fragmento de este tipo puede resumir concreta y metafóricamente algo que no haya sido mostrado por las imágenes cinematográficas, pero que, sin embargo, constituye parte de la narración específica multimedial de la película, o puede rememorar bajo la forma de una repetición interna algo que ya hemos visto, o puede poner de manifiesto aspectos del texto que se mostrarán relevantes más tarde. Con esta forma de auto-referencia nos podemos encontrar en cualquier tipo de película, dado que no constituye exclusivamente una figura retórica de la película reflexiva. La relevancia reflexiva de este tipo de mise en abyme depende de su propio papel en el texto: acentuar el carácter

${ }^{4}$ Esta interpretación heterogénea se justifica porque vivimos en la época de los textos híbridos y porque la teoría misma no puede dejar de impregnarse del «espíritu de la época»: las prácticas teóricas resucitan (como el neo-formalismo de Kristin Thompson), los puntos de vista se sobreponen (la semiótica al psicoanálisis, por ejemplo, en los trabajos tardíos de Metz), los términos teóricos se combinan (como por ejemplo los términos del formalismo recogidos por la teoría cognitiva de Bordwell). 
reflexivo o contribuir solamente a una dramaturgia multimedial de la película.

En realidad, este problema se parece de algún modo a la posibilidad de hacer la distinción entre la representación icónica y la mise en abyme de las que habla Mieke Bal (1978: 128). En su opinión, el concepto de espejo textual podría parecerse al del icono que representa el significado sobre la misma base de una semejanza. La autora nos recuerda que no todas los desdoblamientos pueden ser considerados mises en abyme. El libro que aparece dentro de un libro, la película en la película, puede ser una representación icónica que no refleja todos los aspectos del texto integral. En el caso de la intramedialidad cinematográfica, las distintas representaciones mediales como las pinturas en las paredes, las fotos o la música diegética (es decir escuchada en la radio o cantada por los personajes, no la de la banda sonora sobrepuesta a la imagen), en la mayoría de los casos, contribuyen sólo a la realización de un decorado lo más auténticamente posible, mientras que si tienen un papel dramático (constituyen elementos-clave, por ejemplo en un thriller), no sobrepasan la importancia que tienen de costumbre en la vida real: nos recuerdan algo, constituyen emblemas del estatuto social, o se les mira como a objetos de rito, etc.; por consiguiente, son representaciones icónicas.

Quizás un ejemplo concreto sería más convincente. En la película de Alfred Hitchcock, Rear Window (1954), sobre cuyas características reflexivas se ha escrito mucho, al principio y al final, un papel especialmente importante lo tienen las fotos mostradas en el apartamento del protagonista y en las portadas de algunas revistas. Sus funciones se parecen a la de los flash-back, o a la técnica del flash-forward, porque nos «cuentan» quién es y qué ha pasado con Jeff, el porqué de su silla de ruedas. El accidente, cuyas consecuencias vemos en la pantalla, pasó antes, las fotos de la pared nos muestran las imágenes en un flashback, pero al mismo tiempo, constituyen un elemento que presenta la fuente de todas las complicaciones en la película: son una prueba de los objetivos del personaje y de su espíritu aventurero. El final de la película rima perfectamente con el comienzo, porque aparecen de nuevo dos imágenes del marco de la imagen cinematográfica: las de la portada de un libro y de una revista para mujeres, ofreciendo un desenlace ambivalente a la relación de la pareja de la película. A pesar de todas las técnicas reflexivas que dominan en la película, el papel de estas fotos consiste más bien en la construcción de una dramaturgia austera, económica, que puede ser considerada típica de la expresión 
visual cinematográfica ${ }^{5}$. Encontramos otro ejemplo del empleo de la misma técnica al final de la comedia romántica inglesa de gran éxito, Four Weddings and a Funeral (1994) del director Mike Newell; esta vez, por repetición, las fotos que recuerdan las bodas ya vistas en la película y anuncian las nuevas bodas que va a haber (o no) después de los acontecimientos mostrados, se vuelven fuente de humor. El uso de las imágenes o de las fotos, en este sentido, se parece al papel de los textos verbales o escritos que rellenan las discontinuidades de la narración visual (como, por ejemplo, el uso de un narrador off screen, que cuenta acontecimientos que no se han visto en la pantalla, o comenta imágenes, casos en los que el texto verbal rellena el vacío dejado por la imagen fílmica). Se parece, pero no es idéntico. La distinción más importante estriba en la misma diferencia del medio de comunicación empleado: si alguien cuenta/comenta/resume verbalmente (o un texto escrito corto tiene el papel de informar al espectador) algo que no hemos visto en la pantalla, información que pertenece sin embargo a la diégesis de la película, entonces esto contribuye, en primer lugar, a un desarrollo más natural, una «suavización» de la estructura narrativa ${ }^{6}$ y facilita la construcción de la fábula ${ }^{7}$ por parte del espectador; en general, sirve al carácter mimético de la película, no al reflexivo. Un resumen fotográfico/pictórico o músico está más cerca, sin embargo, de la esencia del término de mise en abyme, porque necesita una interpretación (connotativa) y su complejidad se parece a la imagen fílmica ${ }^{8}$. Se comprende que las estéticas normativas de película consideren este tipo de técnicas en esencia más adecuadas para la película y superiores a otras modalidades literarias de expresión (como por ejemplo un monólogo prolongado). En fin, precisamente por eso, esta forma de reflexividad diegética no puede ser considerada una auténtica reflexividad intermedial.

5 Esta característica se pone de manifiesto también en la entrevista hecha a Hitchcock por Truffaut, donde explica por qué ha evitado dar estas informaciones a través del diálogo o de otros medios prestados de la literatura, inadecuados para la cinematografía (Truffaut, 1993: 126).

6 Salvo los casos en los que estamos en presencia de un unreliable narrator, las informaciones del cual despiertan dudas en el espectador (Kozloff, 1988: 112-117).

7 El término se emplea según la teoría de la narración fílmica, concebida por David Bordwell, que considera que la fábula es una construcción imaginaria del espectador con la ayuda de unas hipótesis y conclusiones formuladas a lo largo de la película, por tanto modificado de alguna manera frente al significado del término en los formalistas rusos, donde se trata más de la reconstrucción de una estructura básica y no de una construcción como aparece en Bordwell (1985).

8 Las demás formas visuales de expresión y la música tampoco se basan en una semántica léxica y todas se pueden verbalizar de varias maneras (véase el dicho inglés: «una imagen vale tanto como mil palabras»). 
Sin embargo, hay casos en los que la película tematiza su intramedialidad cinematográfica; por consiguiente, a esta auto-representación temática se le añade una reflexividad que tiene como objetivo el proceso de comunicación. En la famosa película de Michelangelo Antonioni, Blow-Up (1966), podemos interpretar algunos fragmentos como reflexiones sobre las posibilidades y sobre todo sobre los límites de semejante resumen intermedial mimético. Las fotos sacadas en el parque condensan los acontecimientos que el fotógrafo (y el espectador) ha visto al comienzo de la película en una serie de imágenes descontextualizadas, arrancadas del tiempo. El fotógrafo las considera como unos «momentos fértiles», de los cuales habla Lessing en su ensayo sobre la estatua Laokoon, e intenta reconstituir y comprender, con su ayuda, lo que en verdad ha pasado. Falla, porque lo único que puede hacer es construir variantes de interpretaciones narrativas. «La lectura» de los signos de las fotos resulta más bien una «escritura», una constitución de sentido. Lotman (1977: 128-140) ha observado que Thomas, de hecho, realiza un análisis estructural de las imágenes a través de su segmentación y su ubicación/análisis en orden sintáctico. Podríamos aceptar esta interpretación si las fotos constituyeran un solo texto delimitado, pero han sido sacadas al azar, cada una de ellas constituyendo, de hecho, un «texto» fotográfico en sí. De esta manera, el fotógrafo mismo debe construir, a partir de unos puntos de referencia visuales (como la trayectoria de las miradas, por ejemplo), las hipótesis sobre las cuales las imágenes y las relaciones entre ellas cobren sentido. Interpreta la fila de fotos como «el texto» coherente y llega, en distintos momentos de la película, a dos interpretaciones totalmente contradictorias.

Al ampliar la imagen fotográfica, la película trae al primer plano un resumen auto-textual como una contextualización intermedial (las imágenes de la película se ubican en el contexto narrativo de las fotos) ${ }^{9}$ y así se cuestiona su capacidad de ofrecer una base sólida de interpretación: lo que debería constituir una prueba incontestable o, por lo menos, un documento con valor referencial, se muestra vulnerable ante la actividad del receptor. $\mathrm{La}$ escena de las fotos puede ser interpretada entonces como una metáfora de la construcción misma del sentido narrativo en el cine.

Al mismo tiempo, en la película podemos distinguir entre otras dos auto-representaciones intramediales: la pintura abstracta de Bill y el

${ }^{9}$ Esta interpretación tiene muchos puntos en común con la formulada por Deborah Linderman (1985), según la cual el sobreponer las fotos a la imagen fílmica inicia un nuevo nivel en la película: la narración «externa» es traspuesta al plano de un comentario meta-textual sobre la formación de los textos narrativos en general. 
fragmento de pantomima. Los dos reflejan el segmento de la ampliación de las fotos y el tema principal. De la pintura, su autor, Bill, dice que no persiguió fin alguno al hacerla (igual que Thomas, cuando tuvo la inspiración momentánea de fotografiar a la pareja del parque); ahora, sin embargo, «un fragmento ha empezado a cobrar significado, igual que la solución al final de las novelas policíacas». El texto verbal vincula la literatura con el juego de los medios, anticipando que Thomas buscará claves en las fotos como si siguiera los esquemas narrativos de los cuentos policíacos. Las fotos ampliadas se volverán, cada vez más, unas superficies manchadas de sombras blancas-grises, parecidas a la pintura abstracta de Bill, que ya no representa nada, se vuelve textura visual auto-reflexiva. «El gris es el color de la teoría - dice Flusser (1990: 35) en su libro sobre la filosofía de la fotografía- que demuestra que de un análisis teórico no podemos re-sintetizar el mundo. Las fotos en blanco y negro cumplen con esta condición: son grises, son imágenes de las teorías».

La pantomima, a su vez, es una metáfora de los procesos semióticos presentes en la escena central de la ampliación de las fotos. Según las imágenes que cierran la película, Thomas entra en un juego que consiste en aceptar un marco (frame) de interpretación de los signos específicos de la pantomima y aceptar las reglas de otro juego (el tenis), que aparece como significado en los signos de la pantomima. De hecho, no presenciamos un partido de tenis, tenemos sólo los signos que lo representan, como tampoco Thomas ha visto ningún crimen, sino sólo unos signos visuales que él ha interpretado en el contexto ofrecido por las narraciones policíacas, ha visto los indicios del crimen en los signos icónicos descontextualizados. La semejanza del proceso de semiosis es acentuada por un elemento común en la banda sonora, en los dos casos, «la entrada» en el contexto, en un «marco interpretativo», viene acompañada por la puesta de manifiesto del punto auditivo subjetivo del personaje: mientras medita sobre las fotos, Thomas ( $\mathrm{y}$ el espectador) oye el ruido de las hojas imaginarias (recordando el lugar representado por las imágenes, que, en sí, no ofrece una clave del misterio, tampoco cuando se le hace una visita personalmente), y en el partido de tenis se oye, paradójicamente, el ruido producido por un balón invisible como un anclaje firme en la referencialidad del juego imaginario. El papel de estas secuencias no es sólo reflejar los distintos momentos de la película, sino realizar una auto-reflexión repetitiva del tema metadiscursivo: el fotógrafo trata de descifrar signos, pero en realidad, no hace otra cosa que construir para sí mismo distintas narraciones, atribuyéndoles distintos marcos de interpretación. Antonioni muestra el medio de la cinemato- 
grafía (con el acento en el morfema «grafía» que proviene de una palabra griega que significa escritura y dibujo al mismo tiempo) en el espejo de los demás medios (la fotografía que es su base, la pintura a la que se parece, la literatura con la que tiene en común la narratividad y los modelos de narración, la pantomima que recuerda el cine mudo y el carácter mágico-ritual, ilusorio de las imágenes fílmicas). Al final constatamos que, atrapado en el laberinto de los diversos procesos semióticos que se reflejan recíprocamente, el protagonista no logra alcanzar la realidad deseada (sólo paradójicamente a través de la ilusión del juego).

En el caso de la creación de Peter Greenaway (1983), The Draftsman's Contract, podemos hacernos la misma pregunta (que se hacen, de hecho, los mismos personajes de la película): ¿la finalidad de los dibujos ( $i$ en blanco y negro!) de la película será predecir o resumir los acontecimientos vividos por los habitantes del castillo, como unos espejos diegéticos? ¿Los objetos que aparecen en los dibujos sugieren un crimen o guardan las huellas del adulterio cometido por Mrs Talman, o constituyen una alegoría que predice el asesinato del artista? ¿Y cómo podemos interpretar el hecho de que dichos dibujos fueron realizados por el director mismo de la película, cuya mano metida en un guante negro aparece en la pantalla? Además de estos dibujos, en la película podemos ver también una serie de pinturas que reflejan aspectos de la narración. En general, los personajes de la película aparecen como esbozos de composición pictórica, en la cual Greenaway utiliza modelos de inspiración estilística, técnicas y cuadros concretos de Albrecht Dürer, Georges de la Tour, William Hogarth, Thomas Gainsborough.

Entre los intertextos pictóricos, quizá el más enigmático sea una «cita» de un cuadro, que parece ser una alegoría que resume todos los aspectos de la narración, no solamente la diégesis primaria. Más o menos a la mitad de la película, Mr. Neville, el dibujante, contempla una pintura comprada por Mr. Herbert, el dueño de la casa, cuya mujer le ha ofrecido el contrato para realizar los dibujos de la propiedad, a cambio de servicios sexuales. La pintura es obra de un artista alemán, Januarius Zick; se trata de una alegoría dedicada a la teoría óptica de Newton ${ }^{10}$. El artista observa (junto con el espectador, a quien se le enseñan fragmentos del cuadro) que ciertos elementos parecen corresponder a la intriga misma de la película: el decorado del jardín, la figura del hombre vencido, las pa-

${ }^{10} \mathrm{El}$ óleo tiene un título muy largo, explicativo: Alegoría del favor hecho a la teoría óptica por Newton. Data de 1785 y se encuentra en Niedersächsische Landesgalerie, Hannover. Las informaciones que se refieren a este cuadro provienen del libro de David Pascoe (1997: 67-92). 
rejas de atrás enfrascadas en una discusión íntima como si tramaran algo, la atmósfera inquietante creada por el contraste de luz y sombras. Todo ello parece recordarle al artista, como si de unas piezas de puzzle se tratara, que algo muy importante probablemente se le ha pasado por alto. Ciertas características anticipan cosas que aparecerán al final de la película, cuando el pintor va a quedar ciego (entonces, retrospectivamente, la alegoría sobre la óptica cobra un sentido macabro) y matado por unos personajes que llevan máscaras y antorchas, al igual que la figura del hombre del cuadro. La diferencia, sin embargo, es muy importante: en la pintura, el personaje de la máscara y la antorcha es derribado, y al final son los asesinos los que aparecen con estos objetos. El espejo está torcido. Al igual que el pequeño espejo que está en el centro de la composición en la pintura original y no refleja fielmente el gesto del personaje que simboliza a Newton. La interpretación detallada de la pintura de Zick no se puede hacer durante la película, porque el poco tiempo en el que se ve no nos lo permite. Se trata de una auténtica intertextualidad multimedial, típica de Greenaway; tenemos que hojear álbumes de reproducciones y leer análisis detallados para poder establecer algunos vínculos entre la película y el cuadro. ¿Pero será de verdad así? ¿No será que Greenaway, el auténtico draughtsman de la película (la palabra significa dibujante y delineante al mismo tiempo), nos da pistas falsas de erudición o búsquedas de indicios, como en las intrigas de los relatos policíacos? En todo caso, la temporalidad acentuada de la alegoría pictórica (de un lado, por el hecho de que sintetiza en una sola visión una sucesión de acontecimientos y, de otro, por la técnica de la película, que fragmenta el cuadro en una sucesión de imágenes), junto al tema de la luz, reflejan el tema metalingüístico de la película: el de la compenetración entre pintura e imagen cinematográfica y la exposición de las verdaderas barreras. Como por ejemplo, la temporalidad misma: la narración cinematográfica desarrollada en el tiempo y los procesos de interpretación basados en la auto-corrección retrospectiva y la anticipación de las probables variantes de desenlace, o la utilización de la luz: como una técnica en la pintura y como el material de proyección de la película ${ }^{11}$. Barreras que se muestran infranqueables entre los dos medios.

11 En la película, justo antes de que se vea el cuadro, hay un momento en el que de repente el cambio de las condiciones ópticas (el pasaje de una nube por delante del sol) cambia en realidad todo el paisaje del jardín que cobra vida y pasa de representar un objeto a ser un acontecimiento en sí. Mr Neville se dirige a la señora Herbert con estas palabras ambiguas: «Es el momento, señora». Avisa que ha llegado el momento para un nuevo encuentro, pero llama también la atención sobre lo que pasa con el paisaje cinematográfico frente al pictórico. 
El papel de las representaciones de otros sistemas de comunicación es muy parecido en la película de Alain Robbe-Grillet La Belle Captive (1982), donde la música de Schubert (el cuarteto titulado La Muerte y la muchacha) refleja el tema de la película: el regreso de la novia de entre los muertos, tema elaborado, entre otras, por una serie de intertextos literarios (la película retoma un cuento antiguo, trabajado por varios escritores, por ejemplo Goethe en la balada La Novia de Corinto).

\section{REFLEXIVIDAD AUTO-TEXTUAL ESTILÍSTICA}

Tal y como hemos visto en los ejemplos propuestos, la reflexión autotextual temática puede ser completada también a través de un desdoblamiento en el plano metapoético/metalinguístico. A través de las posibilidades intramediales generales del cine, los distintos niveles textuales y mediales en la película se pueden reflejar recíprocamente. En la película $B l o w-U p$, aparte de los aspectos ya mencionados, tanto el estilo de vida del protagonista como su estilo de fotografiar presentan características similares al estilo de toda la película, entonces presenciamos una mise en abyme poética (que se refiere en parte a lo que Dällenbach ha llamado «mise en abyme du code»). La forma de ser y de trabajar de Thomas es la de saltar de una idea espontánea a otra, la dramaturgia de toda la película se adapta a esta característica: presenciamos comienzos de acciones sin que finalicen, nos trasladamos de un contexto a otro, y lo que parecía tener sentido en un lugar deja de tenerlo en otro (la escena de la anhelada guitarra, que se transforma en algo digno de tirar a la basura, es muy elocuente). En el plano de las imágenes, la cámara cinematográfica de Antonioni alterna, caprichosamente, los planos más convencionales (los que reflejan el punto de vista subjetivo del personaje o se asocian a éste) y los puntos de vista poco habituales, impersonales, que ponen de manifiesto las características artificiales de la composición fílmica.

Las fotos enseñadas en el proceso de producción muestran a sus modelos, al igual que Antonioni utiliza a sus actores en el cuadro del decorado fílmico. La escena que ocurre en la planta del estudio, que precede la aparición de los modelos, en la que vemos a Thomas solo, entre las paredes de vidrio, refleja literalmente lo que el fotógrafo realiza: la imagen del estudio parece desprendida de la ubicación concreta, la composición parece estar dibujada sobre el papel, las paredes no se ven, en el borde de la pantalla aparece solamente una franja blanca, como un marco de la foto sin retocar todavía. 
The Draughtsman's Contract puede ser considerado, desde muchos puntos de vista, como una re-escritura de la película $B l o w-U p$; entre otros, retoma también este lado metapoético. El dibujante de Greenaway procede de la misma forma que el director de la película. En las escenas del jardín, la casa y el mismo dibujante se nos muestran tal y como Mr. Neville dibuja la propiedad ${ }^{12}$. El paralelismo entre dibujo y película es subrayado por el hecho de que, de nuevo, asistimos, igual que en la película de Antonioni, al proceso de producción de la representación, al acto de creación. Los cuadros internos de la imagen fílmica, que reflejan la delimitación de la misma y que estaban constituidos por los elementos «habituales» del decorado en Antonioni (ventanas, puertas u objetos del estudio), aquí se transforman en cuadros explícitos y multiplicados, porque vemos el jardín gracias al instrumento del dibujante (un marco doble, en metal, rodeando unas rejas), mientras al dibujante, a su vez, nos lo enseñan gracias a estos instrumentos. De costumbre, Mr. Neville dibuja sentado, imponiendo su ángulo de visión en casi todas las imágenes al aire libre; la cámara de Greenaway se conforma con la visión del dibujante, graba muchas veces desde la perspectiva de una persona que está sentada.

\section{REFLEXIVIDAD MEDIAL GENERAL}

La autotextualidad que implica relaciones intermediales tiene muchas veces, también, la capacidad de tematizar explícita o implícitamente las relaciones entre distintos medios; así, se confrontan sus posibilidades y sus límites. Esta tendencia de los textos intermedializados cinematográficamente se manifiesta a través de diversas figuras poéticas. De éstas, señalamos las siguientes:

\subsection{Diferentes representaciones mediales como metáforas de la película}

Cada vez que nos encontramos una mise en abyme en el plano del lenguaje, tenemos, en cierta medida, metáforas de la expresión o de la

12 En realidad, como ya lo hemos dicho, Greenaway es el verdadero autor de los dibujos, no sólo el guionista, por tanto esta identificación es más que metafórica. 
producción cinematográfica. Sin embargo, hay casos en los que el objetivo del juego intermedial iniciado por la película es situar la película en el espejo de las demás artes, que acentúan características cinematográficas. El ejemplo de la película Blow-Up sirve también en este sentido; las películas de Greenaway, sin embargo, no se pueden incluir en esta categoría, ya que en ellas las artes están juntas en el mismo plano y se compenetran, teniendo como resultado un cine realmente híbrido o intermedial.

La última película de Antonioni, Par-delà les nuages (1995), realizada junto con Wim Wenders, también está repleta de fragmentos meta-representativos. De hecho, éstos aparecen en las partes de unión entre los episodios realizados por el maestro Antonioni y son la contribución de Wenders como un homenaje a las películas de Antonioni. Su protagonista es guionista y hay muchas referencias implícitas a las películas de Antonioni (el uso de la cámara fotográfica recuerda Blow-Up, el de la niebla Identificazione di una donna, la última gran película anterior a ésta, realizada en 1982). Antes del último episodio, sin embargo, tenemos un fragmento intermedial que combina este tipo de remember con una meditación más profunda sobre el medio cinematográfico. Aparecen los conocidos actores de La notte (1961), Marcelo Mastroianni y Jeanne Moreau, envejecidos y auto-representándose de alguna manera en una escena alegórica. Mastroianni es un pintor que hace una copia de una pintura de Cézanne. Sorprendentemente, no está delante del cuadro, sino delante del paisaje (ya cambiado) que ha inspirado la respectiva pintura: por tanto no ejecuta una copia, sino una reproducción del original en el sentido concreto de la palabra. Más tarde, en el pasillo del hotel, vemos a John Malkovich, el director de la película, imitando los gestos del retrato de Cézanne, colgado en la pared.

Reproducción y gesto: éstas son las nociones que sintetizan la esencia de las escenas. El diálogo lo refleja. (J. Moreau: «¿Para qué necesita una copia? [...] Una reproducción fotográfica de un cuadro o una foto del paisaje serían suficientes»; M. Mastroianni: «Sabe, creo que cada hombre que reproduce el cuadro de un gran artista, tiene la oportunidad de encontrar, aunque sea de casualidad, el gesto adecuado»; J. Moreau: «La copia del gesto»; M. Mastroianni: «Encontrar, aunque sea un solo gesto, me proporcionaría más satisfacción que cualquiera de mis propios movimientos con el pincel».) La esencia de un arte es el gesto artístico creador, lo único que se puede imitar sin plagiar el original: lo que Wenders intenta hacer 
con su contribución en la película. Y la maestría de Antonioni es comparada con la pintura de Cézanne. Y no por casualidad, ya que especialmente sus películas de los años 50-60 (como por ejemplo L'eclisse, de 1962), para emplear los términos de la teoría del arte de Panofsky, tienen un carácter «estereográfico-cristalino», que ha sido muchas veces comparado con el estilo de Cézanne. La pintura es, en realidad, solamente una excusa para hablar de la película y recordar la reflexividad y los temas meta-linguísticos de las películas de Antonioni.

\subsection{La tematización del derribo de las barreras mediales}

\subsubsection{El pasaje a otro nivel narrativo}

Un fragmento intermedial incluido en un texto puede tener el papel de abrir una ventana hacia otro nivel narrativo. En el caso de las películas clásicas no-reflexivas (que hacen que su medio sea «invisible», ya que concentran la atención en lo mostrado), ésta es una técnica convencional, subordinada a la continuidad temática de la narración. Vemos a menudo cómo cuadros, fotos, piezas musicales o citas literarias tienen la función de liberar los recuerdos o de guiarnos en el mundo de la imaginación, de transportarnos en el tiempo, etc. El uso de estas intermedialidades como clichés retóricos se parece a las funciones de otras técnicas de relación.

En el caso de las películas reflexivas, que exponen su multimedialidad con naturalidad, esta técnica significa, en realidad, «una transdiegetización heterosemiótica» o «transposición pragmática», como la describe Jost (1993: 229), a través de la cual se consigue (o se intensifica) una auto-reflexión de la estructura narrativa, una deconstrucción de la narración lineal. Véase, por ejemplo, la película L'année dernière à Marienbad (del director Alain Resnais, 1961), en la cual la escena de teatro incluida trastoca el orden cronológico en la película mediante la inversión del orden de presentación como un cuadro de la película. $\mathrm{O}$ el efecto trompe l'oeil de las pinturas y las postales (todas copias de Magritte) al construir un vínculo entre la realidad y el mundo de los sueños, de la fantasía, imitando al mismo tiempo la estructura paradójica del cuadro titulado Condition humaine (1935), de René 
Magritte. Un procedimiento que es, de hecho, bastante común en la prosa postmoderna ${ }^{13}$.

\subsubsection{Mise en scène del espacio imaginario: más allá y delante de la pantalla}

\subsubsection{1. ¿Ventana u obstáculo?}

«La pantalla es un muro y los muros existen para que los franqueemos» dice Jean-Luc Godard (apud Druckenhaner, 1996: 260), entre otras confesiones semejantes, como por ejemplo: «quisiera entrar en la imagen misma» (apud Paech, 1989: 61). En sus películas ha elaborado toda una serie de técnicas para poder «pasar más allá de la imagen» o "grabar las imágenes desde atrás» (apud Paech, 1989: 61): la integración del proceso de producción en la película (la película que se rueda bajo nuestros ojos), la propia presencia de Godard en la película, a veces no sólo como actor (o él mismo), sino también como narrador of screen (en Vivre sa vie o en Le mépris) y también prestando su voz a un personaje (Jean-Paul Belmondo habla con su voz en Charlotte et son Jules). A la entrada del autor en la imagen, por detrás de la cámara, le corresponden simétricamente los personajes que miran directamente hacia la cámara, por tanto aparentemente a los ojos de los espectadores y también aparentemente, dirigiéndose a éstos directamente. Esta técnica valoriza el espacio de delante de la pantalla, y así le toca al espectador franquear las barreras de la imagen. Lo mismo pasa cuando Godard mezcla personajes «reales» con personajes ficticios: por ejemplo, en la película Vivre sa vie (1962), el filósofo Brice Parain o en Le mépris, Fritz Lang. En realidad, esto pasa a menudo también por la manera en la cual el guionista emplea a los actores (según la concepción de Brecht): los personajes de sus películas no son sólo caracteres imaginarios, sino que guardan también la personalidad del actor que los interpreta (Brigitte Bardot, por ejemplo, en Le mépris, es la famosa $B . B$. pero también la mujer del escritor y los dos ámbitos de significación son igualmente importantes).

13 Brian McHale describe detenidamente estas técnicas en la literatura postmoderna (1987: 112-133). 


\section{ÁgNes Pethö}

Una tematización irónica de las barreras entre el mundo cinematográfico y el mundo real es la famosa escena de Les carabiniers (1963), en la que Michel-Ange (!) confunde el mundo de la pantalla con la realidad y trata literalmente de pasar más allá de la pantalla rompiendo la tela. Joachim Paech (1989: 61) se pregunta si en realidad esta escena quiere decir que la única modalidad de penetrar las imágenes es destruirlas. La transformación del marco en una puerta hace que la imagen carezca de distancia estética. En la recepción mágica de las imágenes (que es la base de lo verídico de la representación mimética), todo lo que constituía la realidad del «más allá» de la pantalla/el objetivo de la cámara se confunde con la representación, la realidad tapando la imagen como artefacto. Mirado desde la parte de acá de la pantalla, el medio utilizado (la cinematografía, «el aparato», en el sentido empleado por Walter Benjamin o Flusser) es lo que se interpone entre el espectador y la realidad «del más allá», sigue las coordenadas de la realidad en los textos reflexivos, cubriéndola en gran parte. Greenaway, en la película The Draughtsman's Contract, tematiza implícitamente esta cualidad de las formas de representaciones de abrir visiones, por un lado, de intervenir como obstáculo, por otro lado (véase el papel de los dibujos y de las sombras).

Las consecuencias de este «acá» y «allá» tienen también otro ámbito de manifestación importante: las citas. El contraste entre las obras de Jean-Luc Godard y Peter Greenaway quizá sea un buen ejemplo. Hemos dicho ya que Godard utiliza muchos personajes «reales» en sus películas: el filósofo Brice Parain aparece en el papel de «filósofo» en la película Vivre sa vie. Es probablemente, al mismo tiempo, un conocido del guionista y una «lectura», una experiencia intelectual suya. El filósofo (entre comillas y fuera de ellas) habla en la película de sus propias ideas filosóficas, como parte del diálogo ficticio. De todo esto resulta que es imposible establecer qué es cita y qué no lo es, cuando el personaje/«el personaje» se cita/«cita» a sí mismo. Se sobreponen no sólo los niveles de la realidad y de lo imaginario, sino también varios niveles de citas: porque los amigos artistas que se mezclan con los actores/personajes de las películas del guionista son, por lo tanto, «citados» por el autor, representan sus propios textos o «narraciones», como auto-citas.

Por supuesto, en la concepción de Godard «todo es cita, si saco una foto del Arc de Triomphe, es una cita. Si voy por la calle hojeando un libro, también es una cita» (apud Brodwell, 1985: 320). Cuando me acerco a ella desde el carácter de intermediario de la cámara, la imagen no es más que una cita de la realidad: una rememoración/un reconoci- 
miento (según las teorías cognitivas) o una actualización (como lo sugiere el origen de la palabra y como decía Christian Metz), y esta cualidad se suprime cuando la mirada traspasa como a través de una ventana de vidrio «más allá» del marco. La ambivalencia de las imágenes está siempre presente y Godard la valoriza; en sus discutidas citas, hay siempre una posibilidad de confusión entre la dualidad de éstas: un libro en la mano de un personaje o una cinta de vídeo recogida de una estantería puede representar la metáfora del conocimiento, o una indicación intertextual compleja, pero, en la mayoría de los casos, sentimos también el hecho de que estos gestos pertenecen a una escena de vida: la cita del texto se combina con la citalla representación del gesto.

En el caso de Peter Greenaway, sin embargo, el carácter de cita es unilateralmente amplificado por las técnicas de una cinemato(picto)grafía relevante: los marcos interiores multiplicados, las composiciones de plan tableau, la multimedialidad acentuada por diversos textos, logran «poner» la imagen «entre comillas», incluso cuando (por falta de erudición) no podemos identificar la cita en sí.

\subsubsection{La extensión del espacio}

Por otra parte, hay procedimientos que facilitan las posibilidades de entablar un diálogo interartístico, procedimientos a través de los cuales la imagen fílmica parece extenderse al espacio imaginario. Se trata, en primer lugar, de unas técnicas tomadas de la pintura, por las cuales la imagen fija (en el cine, el marco fijo) puede abarcar las dimensiones imaginarias virtuales que la composición implica. Las técnicas elaboradas por la pintura se sobreponen a las técnicas corrientes de la internalización del espectador de la película narrativa clásica ${ }^{14}$. Un ejemplo en este sentido lo sería la perspectiva inversa utilizada por Greenaway en las escenas de interior de The Draughtsman's Contract. Dado que estas composiciones se muestran ideales para establecer una relación con el espectador (se parecen al área óptica de las sensaciones visuales corrientes), están mejor capacitadas para conectar el espacio interior de la pantalla con el exterior. Cierta inversión de esta técnica

14 Por eso el espectador se siente como participante de la imagen y de la acción fílmica, el espacio del espectador parece continuar en el espacio de la película. Estas técnicas han sido muy bien descritas por Noel Burch (1990). 
encontramos en la película A Zed and Two Noughts (1985), en la que Greenaway graba, desde la posición de la pantalla cinematográfica, a los espectadores de una sala de proyección alternando con las imágenes más convencionales.

\subsubsection{El reflejo en el espejo}

La introducción de la imagen reflejada por espejos o paredes de vidrio, que es empleada en la misma medida tanto por Antonioni como por Godard, «vuelca» la dimensión del más allá de la pantalla sobre el plano de la pantalla y, comprimiéndola de esta manera, le confiere ambiguiedad (el espacio se extiende y se comprime al mismo tiempo). Puede ser un trompe l'oeil: es decir, confundirla con una imagen simple, sin observar el marco del espejo (la famosa película de Tarkovski El espejo, 1974, se ha basado, en gran medida, en esa técnica). Se puede presentar como una imagen de una imagen: Greenaway utiliza en The Pillow Book muchas imágenes sobrepuestas, en las cuales los puntos de vista se reflejan recíprocamente, como unos espejos colocados sobre la pantalla, o, en el caso de las películas de Antonioni o Godard, que presentan a los personajes y su reflejo en un solo marco. Esta forma acentúa cada vez el carácter artificial de la imagen y ofrece posibilidades de comparación con técnicas de pintura. En Vivre sa vie, la protagonista, Nana, se nos muestra de esta manera, y paralelamente aparecen unas composiciones que imitan cuadros famosos de la época del impresionismo (por ejemplo, el marco del comienzo de la película reproduce elementos de la pintura de Manet Un Bar aux Folies-Bergères); Greenaway, a su vez, incluye una imitación del mismo cuadro de Manet en The Pillow Book, en la escena del bar, y sus procedimientos de esta película y de Prospero's Books se pueden comparar a menudo con las obras de Magritte (que también sobreponen varios puntos de vista).

\subsubsection{Metáforas espaciales del universo textual}

Con sus múltiples posibilidades de espacialización, el cine puede construir una dimensión espacial imaginaria virtualmente infinita, que 
puede funcionar como espacio metafórico del universo textual memorial. Esto pasa muchas veces en el caso de los planos que ponen en escena cuadros como tableaux vivants y a los cuales la música, el texto, les añaden nuevas dimensiones semánticas. Podemos citar una escena memorable de The Pillow Book, donde Greenaway parece metaforizar la idea del cine realmente intermedial, el ideal del «cine sin paredes» ${ }^{15}$. El protagonista, Jerome, visto como una metáfora, es él mismo un espejo cultural: es intérprete, conoce varios idiomas, por su estilo de vida realiza un vínculo entre las culturas del Este y las del Oeste, tal y como, por su ambivalencia sexual, combina los papeles masculinos con los femeninos. Por tanto, es una réplica perfecta del personaje femenino central, que es considerado un indicador que apunta a los cuatro puntos cardinales. En la escena en la que Jerome presenta el primer «libro» escrito por Nagiko y que le había sido enviado al editor, y está desnudo, cubierto de signos misteriosos, pintorescos (el texto del «libro»), en medio de la habitación, aparece como un axis mundi del universo textual. Sobre un fondo musical grandioso, la cámara le rodea y con este movimiento circular vemos que, en realidad, la forma cúbica de la habitación se abre en todas las direcciones: en los dos lados, tenemos puertas abiertas, un lado es el de la ventana, y el último está cubierto de estanterías de libros, que de manera concreta no es una forma visual abierta, pero, metafóricamente, tiene la capacidad de «abrir» el mayor número de dimensiones.

\subsubsection{La pintura del espacio con la ayuda de la luz}

La capacidad de la técnica fílmica de servir de mediadora entre las demás artes se sugiere en las películas de Greenaway «pintando» la imagen con la ayuda de la luz colorada (como lo hemos visto, por ejemplo, en las escenas exteriores de la película Drowning by Numbers o en Prospero's Books). Por un lado, al realzar la materialidad de la luz como «materia primaria» de la que se componen las imágenes, se acerca la película a la pintura, de la que toma prestados

${ }^{15}$ Cada imagen fílmica se puede encuadrar en el contexto general de la historia de la película, pero, al mismo tiempo, pertenece también al contexto infinito de la imaginación (literaria/pictórica/musical, etc). El ideal del «cinema without walls» representa la base de los análisis intertextuales/intermediales de T. Jefferson Kline (1992), entre otros. 
técnicas y modelos de composición (la película $A$ Zed and Two Noughts es una auténtica enciclopedia de la luz, se pueden contar trece fuentes distintas de luz empleadas, apud Hacker, Price, 1991: 220). Por otro lado, la luz se relaciona con la literatura, gracias a los textos hechos de signos luminosos, que, en realidad, no se inscriben en una superficie plana, sino en el espacio. En general, los personajes situados en la trayectoria de luz del proyector y que la reflejan/deforman en las películas de Greenaway (A zed and Two Noughts, The Pillow Book) o de Godard (Scénario du film Passion,1982) tematizan, por la descomposición de la luz móvil y de la imagen, la esencia de la expresión cinematográfica. De manera concreta, el guionista traslada el aura mágica de la sala de cine a la pantalla y ejemplifica el estatuto intermedio poco constante de las construcciones semánticas del autor/receptor, que toman forma/se deforman en el espacio imaginario entre representación y representado. Joachim Paech (1989: 64) considera que, en el sentido más amplio, estas técnicas (al igual que todas las películas que le sacan provecho al potencial intermedial) demuestran que para el cine no hay nada que le sea exterior; hay sólo imágenes que tienen relaciones con otras y otras imágenes. Podemos añadir: el cine es el calidoscopio del universo intermedial que, cada vez más, nos muestra configuraciones distintas de la combinación de las más diversas formas de expresión.

\subsubsection{Transposición explícita (y distorsionada)}

Una figura irónica del diálogo de las artes iniciado por el cine intermediático lo constituye el caso en el que tenemos referencias verbales explícitas a una forma del arte como metáfora de otro arte, pero ésta tiene el objetivo de ironizar recíprocamente los medios artísticos y de cuestionar su autoridad. Godard, por ejemplo, hace muchas referencias a la pintura o a la literatura en sus películas, pero cada vez se refiere en realidad a la película. Un solo ejemplo de Pierrot le fou (1965): «Tengo una formidable idea para una novela: no escribir sobre la vida de los hombres, sino pura y simplemente sobre la vida. Al igual que entre los hombres existen el espacio y los colores. Deberíamos llegar aquí. Joyce lo ha intentado, pero se debería hacer mejor, mucho mejor.»

Por otra parte, en varias películas de Greenaway aparecen en paráfrasis algunas citas de la historia de la película, que se trasponen al 
marco de la pintura. En The Draughtsman's Contract tenemos una reformulación de la observación irónica atribuida a Truffaut: «la película inglesa es una contradicción de términos», siendo la observación de Greenaway: «la pintura inglesa es una contradicción de términos» (apud Haecker, Price, 1991: 200). Otra paráfrasis nos recuerda el célebre ejemplo de un estudio de Einstein (escrito en 1948) sobre la dramaturgia de los colores, estudio según el cual, nadie debe pensar en la composición de los colores hasta que no aprende «a ver, en tres naranjas en la hierba, no sólo tres objetos en la hierba, sino tres manchas naranjas sobre un fondo verde» (Einstein,1998: 289). En la película tenemos el siguiente fragmento de diálogo entre Mr. Neville y Mrs. Talman: Mr. Neville: «El segundo juego de dibujos está todavía envuelto en misterio, pero me estoy acercando, paso a paso, a la esencia del problema»; Mrs. Talman: «Quizá al corazón de mi padre, Mr. Neville» (la señora aludiendo al hecho de que era posible que su padre hubiera sido asesinado y los dibujos descubrirían indicios del crimen). Mr. Neville: «Una mancha roja como la sangre en la hierba verde brillante» (aludiendo a que, en realidad, el crimen es sólo una excusa para formular, en el lenguaje cinematográfico, problemas de la representación pictórica y fílmica) ${ }^{16}$. A lo que Mrs. Talman responde con sarcasmo: «Qué pena, Mr. Neville, que sus dibujos sean en blanco y negro».

En la película $A$ Zed and Two Noughts, la alusión a la pintura, distorsionada en el espejo torcido del cine, es todavía más macabra. El filme se halla bajo la influencia de la técnica de Vermeer, cuyos cuadros más famosos están reproducidos en la película y de los cuales también se habla. Alba Bewick menciona lo interesante que resulta el que en las pinturas de Vermeer nunca se vean los pies (de las mujeres), mientras que, en la película, el doctor Van Meegeren (!) le amputa a Alba las dos piernas, lo que provoca la réplica de ésta, en clave de humor negro: «Así, voy a caber con facilidad en el ataúd». $O$ en los primeros planos de la película, podemos añadir las composiciones que «recortan» las figuras humanas de la película. Quizá recordemos también a los primeros espectadores de cine, que miraron horrorizados los cuerpos fragmentados en la pantalla. La alusión inocente a la pintura se ha concretado de tal manera que la película ha logrado desvelar «territorios» semánticos hace mucho sumergidos en el «subconsciente» de la experiencia cinematográfica.

16 Para una acentuación del efecto pictórico de las imágenes de la película, Greenaway ha «teñido», con la ayuda de unos filtros especiales, la hierba del jardín, para que tenga un efecto de lo más brillante posible. 


\subsubsection{Ekphrasis}

Ekphrasis es el nombre de un procedimiento textual que tiene su origen en la retórica de la antigüedad y que ha significado una descripción de lo más detallada de un cuadro o de una estatua, descripción que podría rivalizar, en cuanto a plasticidad, con la expresividad de la pintura o de la escultura, por tanto la noción se refiere a un caso en el cual un texto verbal es reproducido con el fin de competir con las artes plásticas. En la teoría de la medialidad, hoy el término ha empezado a ser empleado también en un sentido más amplio, refiriéndose a todos los intentos en los que las obras de arte, o las características de un medio artístico, se vuelven objetos de otra obra, de otro medio. Dentro de las tendencias ekphrasticas, el problema más interesante está constituido por las referencias recíprocas entre los diferentes sistemas semióticos implicados en la relación entre los distintos textos. En su significado original, el término ha denotado la tendencia de la lengua de franquear las barreras hacia la visualización. Y para los casos en que las imágenes tratan de dar un equivalente al texto verbal, se ha introducido el término de ekphrasis inversa (Krieger, 1992). En el cine, de hecho, podemos hablar no sólo de una tal ekphrasis inversa, sino también de tendencias ekphrasticas múltiples/multidimensionales.

Se ha dicho ya (Leutrat, 1989; Paech, 1989; Müller, 1996), que en las películas reflexivas que tematizan su propia medialidad, la película parece situarse de alguna manera entre los demás ámbitos. Si analizamos con más detenimiento estos ejemplos, vemos que esto significa también que la intermedialidad de una película no se reduce casi nunca a la relación entre dos ámbitos, o formas de arte. La secuencia Van Gogh de la película de Akira Kurosawa, Dreams (1990), puede ser considerada una excepción, un ejemplo aislado, donde sólo la película y la pintura se confrontan, como una ejemplificación didáctica de la teoría de Bazin, según la cual la técnica de la película destruye la integridad de la obra pictórica y la narrativiza (Véase Bazin, 1995).

Existen también los casos más frecuentes en los que una composición pintoresca de la película puede ser considerada el equivalente cinematográfico de la figura retórica de hypotyposis (un procedimiento de la antigua retórica en el que el orador presentaba su tema de lo más vivo y pintoresco posible para impresionar). El resultado de las composiciones de este tipo es una imagen parecida a la pintura, con la que puede haber analogías estilísticas y de la cual puede incorporar 
modelos (tal y como el fenómeno ha sido descrito por Jost, 1993: 228). En la mayoría de los casos sin embargo, tenemos una serie de conexiones intermediales.

Lo que no se ha explorado suficientemente hasta ahora es la naturaleza de estas múltiples conexiones que han venido imponiéndose desde que la nouvelle vague de origen francés ha introducido este tipo de «juegos (inter)linguísticos» en el ruedo cinematográfico. En otro estudio mío, en vías de publicación ${ }^{17}$, he tratado de presentar dos posibles modelos de este tipo de intermedialidad, que se puede describir también como ekphrasis multidimensional. Sin repetir lo escrito detalladamente allí, hago aquí un resumen de las ideas principales.

\subsubsection{Una tendencia de reflexividad repetitiva y permutable}

Los mejores ejemplos pueden ser sacados de las películas de la nueva ola francesa, sobre todo las de Godard o Truffaut. La esencia de esta tendencia consiste en el hecho de que la imitación de otra forma de arte se vuelve en realidad una puerta para entrar en el mundo de las relaciones intermediales multidimensionales. El mismo tema se repite mediante representaciones mediales distintas y multiplicadas, que «se traducen» de esta manera recíprocamente y que resultan de un continuo distanciamiento del texto de la referencialidad. El ejemplo del episodio del Retrato ovalado de Vivre sa vie es elocuente: una ekphrasis literaria, citas de sociología, imitaciones de pintura, la película, la foto se sobreponen para realizar un retrato de la actriz Anna Karina/del personaje Nana/del tipo de la joven prostituta retratado por los (inter)textos aparecidos, etc.

3.2.4.2. El ritual inter-semiótico de la intermedialidad postmoderna

En las películas de Peter Greenaway se da, en realidad, un carnaval de las artes, en el cual cada uno aparece con la máscara del otro: no sólo que

17 Se trata de una comunicación presentada en el VII Congreso IASS-AIS (Dresden, 1999). El trabajo se va a publicar en inglés en el volumen que contiene los estudios presentados. 
la película trata de rivalizar con ellas, sino que también la literatura o la pintura tienden a afirmarse con más fuerza a través de la película que, muchas veces de manera impactante, da vida a las metáforas que pueden describir la esencia de las demás artes/medios, en realidad a la manera en que, a través de ellos, entendemos el mundo. Estas compenetraciones (que no son «transcodificaciones» repetitivas, sino que se basan en modelos rituales) constituyen el tema principal de sus películas, tratando a la vez de manera subversiva el mismo pensamiento metafórico.

\section{Referencias bibliográficas}

BAL, M. (1978). «Mise en abyme et iconicité». Littérature 29, 116-128.

BAzIN, A. (1995). «Festészet és film». En Mi a film?, 146-152. Budapest: Osiris.

BORDWELl, D. (1985). Narration in the Fiction Film. University of Wisconsin Press.

- (1989). Making Meaning. Inference and Rhetoric in the Interpretation of Cinema. Cambridge, Massachussttes \& London, England: Harvard University Press.

BURCH, N. (1990). Life to those Shadows. Berkeley \& Los Angeles: University of California Press.

DÄllENBACH, L. (1977). Le récit spéculaire, essais sur la mise en abyme. Paris: Seuil.

EISENSTEIN, S. M. (1998). «A színes film». En Válogatott tanulmányok 281291. Budapest: Áron Kiadó.

Flusser, V. (1990). A fotográfia filozófiája. Budapest: Tartóshullám, Belvedere, ELTE BTK.

HACKer, J. y Price, D. (1991). Take Ten. Contemporary British Film Directors. Oxford \& New York: Oxford University Press.

JosT, F. (1993). «Der Picto-Film». En Müller, J.E.; M. Vorauer (Hrsg.), BlickWechsel. Tendenzen im Spielfilm der 70er und 80er Jahre, 223-237. Münster: Nodus Publikationen.

KLINE, T. J. (1992). Screening the Text. Intertextuality in New Wave French Cinema. Baltimore \& London: The Johns Hopkins University Press.

Kozloff, S. (1988). Invisible Storytellers. Voice-Over Narration in American Fiction Film. Berkeley, Los Angeles \& London: University of California Press.

KRIEGER, M. (1992). Ekphrasis. The Illusion of the Natural Sign. Baltimore \& London: The Johns Hopkins University Press.

LeUtRAT, J. L. (1989). «Des traces qui nous ressemblent». En Aumont J., A. Gaudreault, M. Marie (dir.), L'Histoire du cinéma. Nouvelles Approches 183-196. Paris: Publications de la Sorbonne, Colloque de Cérisy. 
LINDERMAN, D. (1985). «Narrative Surplus: the Blow- $U p$ as Metarepresentation and Ideology». American Journal of Semiotics, vol. 3, n. ${ }^{\circ} 4,99-118$.

Lotman, J.M. (1977). Filmszemiotika és filmesztétika. Budapest: Gondolat.

McHale, B. (1987). Postmodernist Fiction. New York \& London: Methuen.

MÜLLER, J. E. (1996). Intermedialität. Formen moderner kultureller Kommunikation. Münster: Nodus Publikationen.

PAECH, J. (1989). Passion oder die EinBILDungen des Jean-Luc Godard. Frankfurt am Main: Deutsches Filmmuseum.

Pascoe, D. (1997). Peter Greenaway. Museums and Moving Images. London: Reaktion Books.

Pynchon, Th. (1993). Granty's Tainbow. New York: Viking Press.

Stam, E.; Burgoyne, R. y Flitterman-Lewis, S. (ed.) (1992). New Vocabularies in Film Semiotics. Structuralism, Post-Structuralism and Beyond. London \& New York: Routledge.

Truffaut, F. (1993). Truffaut-Hitchcock. Paris: Gallimard.

Waugh, P. (1984). Metafiction. The Theory and Practice of Self-Conscious Fiction. New York: Methuen. 